\title{
Entrepreneurial Skill Needs of Secretarial Education Graduates of Colleges of Education for Self Sustainability in Enugu State, Nigeria
}

\author{
E. A. C. Etonyeaku1, J. A. Kanu², H. A. Ezeji' ${ }^{1}$, J. N. Chukwuma1 \\ ${ }^{1}$ Department of Vocational Teacher Education, University of Nigeria, Nsukka, Nigeria \\ ${ }^{2}$ Nigerian Educational Research \& Development Council (NERDC), Abuja, Nigeria \\ Email: natedeh@yahoo.com
}

Received 25 April 2014; revised 20 May 2014; accepted 18 June 2014

Copyright (C) 2014 by authors and Scientific Research Publishing Inc.

This work is licensed under the Creative Commons Attribution International License (CC BY).

http://creativecommons.org/licenses/by/4.0/

(c) () Open Access

\begin{abstract}
The study was carried out to determine the entrepreneurial skill needs required by secretarial education graduates of college of education for self sustainability in Enugu State. Four research questions and two null hypotheses guided the study. The study adopted a descriptive research design that made use of $\mathbf{4 0}$ item structured questionnaire. The population for the study was 238 respondents. The questionnaire was face-validated by three experts. Cronbach Alpha method was used to determine the reliability of the items and a coefficient of 0.75 was obtained. The questionnaire was administered on 238 respondents by the researchers with the help of three research assistants trained by the researchers. Two hundred and thirty-eight copies of the questionnaire were returned and considered valid. The analysis was done using mean for research questions and t-test statistic for the hypotheses. The findings revealed that the $\mathbf{4 0}$ entrepreneurial skill needs were required by the graduates for self sustainability. It therefore was recommended among others that secretarial education graduates should be encouraged to acquaint themselves with all the relevant entrepreneurial skills that will enable them to be self sustained in the society.
\end{abstract}

\section{Keywords}

Entrepreneurial Education, Skill, Secretarial Education, Self Sustainability

\section{Introduction}

The higher educational programmes in Nigeria had fallen short of expectations, and as a result, many of the

How to cite this paper: Etonyeaku, E.A.C., Kanu, J.A., Ezeji, H.A. and Chukwuma, J.N. (2014) Entrepreneurial Skill Needs of Secretarial Education Graduates of Colleges of Education for Self Sustainability in Enugu State, Nigeria. American Journal of Industrial and Business Management, 4, 601-607. http://dx.doi.org/10.4236/ajibm.2014.410065 
graduates of these institutions lack basic skills required by the labour market. The short fall in required basic skills has also resulted in mass unemployment among the graduates. The pace in technological changes in the field of business and education has affected the labour market. The educational programmes at all levels should be made relevant to provide the graduates with the needed entrepreneurial skill needs that should give adequate attention to entrepreneurial development in the country.

To be able to teach entrepreneurship education, the teachers themselves, especially the secretarial education programme of colleges of education should be well equipped with entrepreneurial skills to enable them develop an entrepreneurial orientation necessary for employability.

The secretarial education is a course of study offered in colleges of education, that equips its graduates with practical, professional and entrepreneurial skills. Secretarial education is also an aspect of vocational business education programme that gives training and imparts necessary skills that will provide the recipients with the intellectual and professional background, adequate for their assignment and makes the recipients adaptable to changing situations in the economy. This is in line with the National Policy on Education [1] that one of the objectives of vocational and technical education was to give training and impart the necessary skills leading to production of craftsmen, technicians and other skilled professionals, who will be enterprising and self-reliant. For this reason, secretarial education graduates need certain entrepreneurial skills to operate in the society.

A skill is any established habit of performing a task in a way that is acceptable by a worker in his specialization. It is the ability to use one's knowledge effectively and readily in performing an act or a habit of doing a particular task competently [2]. The concept of entrepreneurship has been defined by academics according to their orientation and understanding of the subject matter. Osborne [3] defined entrepreneurship as a process of creating new systems, processes, mobilizing men, materials, machines and financial resources in order to produce new products or serve new materials. Jain [4] defined entrepreneurship as a behaviour, attitude and an approach to the way people create new values in the market, technology consumption, habits and build sustainable institutions and organizations. The author opined that entrepreneurship involves creating new products, new markets, new businesses, new technology by developing resources and people in a unique way to develop a new organization. The person involved in these activities is an entrepreneur. Arogundade [5] defined an entrepreneur as a person who has developed an ongoing business activity where none existed before. UNESCO [6] defined an entrepreneur as someone who starts or operates a business venture and assumes the responsibility for it. In the same vein, Anyakoha [7] defined an entrepreneur as a person who chooses or assumes risks, identifies business opportunity, gathers resources, initiates actions and establishes an organization or enterprise to meet such market opportunities. Entrepreneurial skills are those activity skills that will enable an entrepreneur to manage his own enterprise. In the context of this study, the entrepreneurial skills are the knowledge, attitudes and behaviours that will enable an entrepreneur to identify business opportunities, stimulate creativity and transform ideas into practical and economic activities for sustainable livelihood. These skills are needed to perform certain activities such as managerial, accounting, marketing, human relations, technical and information and communication technology skills to run an enterprise successfully. Hisrich in Etonyeaku [8] stated that managerial skills are needed for planning, decision making, human relationship, innovative changes, visionary leadership and ability to manage change.

Anyakoha [7] stated that accounting and financial skills are needed to be able to interpret financial statements, knowledge of costing and ability to understand gross and net profit of any business enterprise. The knowledge skill will enable the entrepreneur (graduate) to grasp the understanding of business management while the technical skills will enable him to run the day-to-day activity of this enterprise. Therefore, for the secretarial education graduate to be able to achieve self employment status, requires entrepreneurial skills which will enable him to establish small scale business for self sustainability.

The purpose of this study was to determine the entrepreneurial skills needed by secretarial education graduates for self sustainability in Enugu State. Specifically, the study sought to:

- determine the managerial skill needs required by secretarial education graduates for self sustainability;

- determine the technical skill needs required by secretarial education graduates for self sustainability;

- determine the marketing skill needs required for self sustainability;

- determine the ICT skills required by secretarial education graduates for self sustainability.

\section{Research Questions}

The following research questions were answered by the study. 
1) What are the managerial skill needs required by secretarial education graduates for self sustainability?

2) What are the technical skill needs required by secretarial education graduates for self sustainability?

3) What are the marketing skill needs required by secretarial education graduates for self sustainability?

4) What are the ICT skill needs required by secretarial education graduates for self sustainability in Enugu State?

\section{Hypotheses}

The following null hypotheses were tested at 0.05 level of significance.

$\mathrm{Ho}_{1}$ : There is no significant difference in the mean responses of lecturers and students on managerial skill needs required by secretarial education graduates for self sustainability.

$\mathrm{Ho}_{2}$ : There is no significant difference in the mean responses of lecturers and students on the technical skill needs required by secretarial education graduates for self sustainability in Enugu State.

\section{Methodology}

A descriptive research design was adopted for this study. A descriptive survey design is concerned with specifying the properties of educational and other phenomena [9]. The design is appropriate for this study because it sought the representative views of the lecturers and students on the entrepreneurial skill needs required by secretarial education graduates for self sustainability.

The study was carried out in Enugu State. The state has three colleges of education offering secretarial education programme, namely Enugu State College of Education (Technical) College of Ecumenical Education, Enugu and Federal College of Education Eha Amafu. The choice of the state for this study was necessitated by the adequate number of NCE secretarial education lecturers and students who constituted the respondent for the study and also the growing number of unemployed NCE secretarial graduates who will benefit immensely from the finding of the study.

The population for the study was 238 respondents, made up of 54 business education lecturers and 184 second year students offering secretarial education programme for 2012/13 academic session in Enugu State. The choice of lecturers was because the lecturers were believed to be knowledgeable enough in this field while the students would make use of the skills for lifelong sustainability.

The questionnaire was the instrument used for eliciting responses from the respondents. The questionnaire was divided into four sections: A, B, C and D, which consisted of 40 generated items. Section A sought information on managerial skill needs required for self sustainability of secretarial education graduates. Section B was on technical skill needs, Section C on marketing skills while Section D delved on ICT skills for self sustainability. The instrument utilized a five points rating scale of very highly required (VHR) 5 points, highly required (HR) 4 points, slightly required (SR) 3 points, fairly required (FR) 2 points and not required (NR) 1 point. The class boundary limit for interpreting the results was as follows: very highly required (4.5 - 5.00), highly required (3.5 - 4.49), slightly required (2.5 - 3.49) fairly required (1.5 - 2.49) and not required (0.05 - 1.49). The instrument was face validated by three experts in entrepreneurial education, two from the Department of Vocational Teacher Education, University of Nigeria, Nsukka and one from Federal College of Education Eha Amufu, Enugu State. The comments and corrections were effected and used for the final development of the instrument. The internal consistency of the instrument was determined using test retest with the use of Cronbach Alpha method, which yielded a coefficient of 0.84 showing that the instrument was reliable for the study.

All the 238 copies of the questionnaire were administered by the researchers with the help of three researcher assistants, who helped to collect on the spot the completed questionnaire to ensure a high percentage return rate of the questionnaire.

The data collected were collated and analysed using mean to answer the research questions while t-test was used test the null hypotheses at 0.05 level of significance. If the calculated $t$-value was greater than the table value for the given degree of freedom (df) the null hypothesis was regarded as significant otherwise not significant.

\section{Results}

The results are presented in tables in accordance with the research questions and hypotheses. 


\section{Research Question 1}

What are the managerial skill needs required by secretarial education graduates for self sustainability in Enugu State?

The data presented in Table 1 above showed that all the items listed above had their grand mean above 3.50. This signifies that all the items listed above were accepted by all the respondents. All the items had their calculated t-value less than 1.96 at 0.05 level significance indicating that there is no significant difference in the mean ratings of the responses of the two groups on managerial skills required by secretarial education graduates for self-sustainability in Enugu State.

\section{Research Question 2}

What are the technical skill needs required by secretarial education graduates for self-sustainability?

The data presented in Table 2 showed that item 10 had the highest grand mean of 4.54 . This signifies that communicating ideas, thoughts, information dissemination etc is very highly required as a technical skill required to sustain any business enterprise. Table 2 showed that the t-calculated value ranged from 0.44 to 1.37 at probability level of 0.05 (two tail test) and 236 degree of freedom which are lower than the table value of 1.96 . This shows that there is no significant difference in the mean scores of the groups of respondents on the technical skills required for self-sustainability.

\section{Research Question 3}

What are the marketing skill needs required by secretarial education graduates for self-sustainability?

The responses from the respondents in Table 3 revealed that all the items listed above had their grand mean above 3.50. This implies that the respondents in the two groups upheld that marketing skills as highly required by secretarial education graduates for self sustainability in the society. The cluster grand mean of 4.00 (SD 0.79) showed that all the items fall within the response category of highly required on the marketing skills required for self sustainability of secretarial education graduates in the field of entrepreneurship.

\section{Research Question 4}

What are the ICT skill needs required by Secretarial Education Graduates for Self-Sustainability?

The data presented in Table 4 showed that eight out of the ten items listed above had their grand mean above 3.50 while items 6 and 8 had their grand mean below 3.50. The result further revealed that all the items fall within the response category of highly required and slightly required. Table 4 also showed that the standard deviation (SD) of the items ranged from 0.66 to 1.61, indicating that the respondents were not too far from one another in their responses on the ICT skills required by secretarial education graduates for self sustainability in Enugu State.

Table 1. Mean scores on managerial skill needs required for self sustainability $\mathrm{N}=238$.

\begin{tabular}{|c|c|c|c|c|c|c|c|c|}
\hline \multirow[t]{2}{*}{$\mathbf{S} / \mathbf{N}$} & \multirow[t]{2}{*}{ Managerial Skills } & \multirow[b]{2}{*}{$\bar{X} g$} & \multicolumn{2}{|c|}{$\begin{array}{c}\text { Lecturers } \\
n=54\end{array}$} & \multicolumn{2}{|c|}{$\begin{array}{c}\text { Students } \\
\mathrm{n}=154\end{array}$} & \multirow[t]{2}{*}{ t-cal } & \multirow[t]{2}{*}{ Remark } \\
\hline & & & $\bar{X}_{1}$ & $\mathrm{SD}_{1}$ & $\bar{X}_{1}$ & $\mathrm{SD}_{1}$ & & \\
\hline 1 & Adapting basic steps in setting up business & 4.37 & 4.49 & 0.88 & 4.25 & 0.70 & 0.057 & NS \\
\hline 2 & Planning and co-ordinating business resources & 4.39 & 4.50 & 0.77 & 4.28 & 0.86 & 0.89 & NS \\
\hline 3 & Taking decisions as at when due & 4.18 & 4.38 & 0.72 & 3.99 & 1.04 & 1.41 & NS \\
\hline 4 & Bringing in innovative ideas and changes in the business & 3.89 & 3.99 & 1.16 & 3.79 & 1.17 & 1.02 & NS \\
\hline 5 & Able to receive and attend to relevant & 4.19 & 4.00 & 0.98 & 4.39 & 0.91 & 0.75 & NS \\
\hline 6 & Knowledge of human relations and communicative ability & 4.27 & 4.29 & 0.92 & 4.24 & 0.74 & 1.15 & NS \\
\hline 7 & Setting up appropriate business plans & 4.24 & 4.15 & 0.99 & 4.32 & 0.65 & -0.9 & NS \\
\hline 8 & Able to determine risks and risk management & 4.43 & 4.47 & 0.92 & 4.92 & 4.39 & 0.91 & NS \\
\hline 9 & Able to create, maintain and sustain customers & 3.83 & 3.87 & 1.38 & 3.78 & 1.17 & 0.78 & NS \\
\hline 10 & Able to appraise employees performance & 4.13 & 4.43 & 0.85 & 3.52 & 1.01 & 1.02 & NS \\
\hline
\end{tabular}


Table 2. Mean scores on technical skill needs required for self-sustainability N = 238.

\begin{tabular}{|c|c|c|c|c|c|c|c|c|}
\hline \multirow[t]{2}{*}{$\mathrm{S} / \mathrm{N}$} & \multirow[t]{2}{*}{ Technical Skills } & \multicolumn{3}{|c|}{$\begin{array}{l}\text { Lecturers } \\
\mathrm{n}=54\end{array}$} & \multicolumn{2}{|c|}{$\begin{array}{l}\text { Students } \\
\mathrm{n}=154\end{array}$} & \multirow[t]{2}{*}{$\mathrm{t}-\mathrm{cal}$} & \multirow[t]{2}{*}{ Remarl } \\
\hline & & $\bar{X} g$ & $\bar{X}_{1}$ & $\mathrm{SD}_{1}$ & $\bar{X}_{1}$ & $\mathrm{SD}_{1}$ & & \\
\hline 1 & Operate office machines & 3.99 & 4.10 & 0.90 & 3.87 & 0.81 & 0.44 & NS \\
\hline 2 & Help others to learn needed skills and knowledge & 4.42 & 4.48 & 0.80 & 4.35 & 0.60 & 1.37 & NS \\
\hline 3 & Identify training needs and job information to help others & 4.41 & 4.45 & 0.92 & 4.37 & 0.99 & 0.50 & NS \\
\hline 4 & Demonstrate understanding and adaptability of changes & 4.18 & 4.09 & 0.98 & 4.27 & 0.74 & 1.33 & NS \\
\hline 5 & $\begin{array}{l}\text { Exhibit self-confidence to select appropriate } \\
\text { reproduction processes in collating/binding documents. }\end{array}$ & 4.37 & 4.38 & 0.72 & 4.35 & 0.60 & 0.69 & NS \\
\hline 6 & Proof-reading and preparing mailable documents. & 4.45 & 4.47 & 0.92 & 4.42 & 0.78 & 0.62 & NS \\
\hline 7 & $\begin{array}{l}\text { Generate innovative ideas and new ways to } \\
\text { disseminate information }\end{array}$ & 4.10 & 4.25 & 0.91 & 3.95 & 1.07 & 0.94 & NS \\
\hline 8 & Use different word processing packages/software & 3.89 & 3.79 & 1.16 & 3.98 & 1.18 & 0.53 & NS \\
\hline 9 & Manage materials and facility resources & 4.43 & 4.42 & 0.99 & 4.43 & 067 & 0.70 & NS \\
\hline 10 & $\begin{array}{l}\text { Communicate ideas, thoughts, information and } \\
\text { messages in form of letters, reports manuals etc. }\end{array}$ & 4.54 & 4.50 & 0.77 & 4.18 & 0.92 & 0.69 & NS \\
\hline
\end{tabular}

Table 3. Mean responses on marketing skills needs required by secretarial education graduates for self-sustainability $\mathrm{N}=$ 238.

\begin{tabular}{|c|c|c|c|c|c|c|c|}
\hline \multirow[t]{2}{*}{$\mathrm{S} / \mathrm{N}$} & \multirow[t]{2}{*}{ Marketing Skills } & \multicolumn{3}{|c|}{$\begin{array}{l}\text { Lecturers } \\
\mathrm{n}=54\end{array}$} & \multicolumn{2}{|c|}{$\begin{array}{l}\text { Students } \\
\mathrm{n}=154\end{array}$} & \multirow[t]{2}{*}{ Remark } \\
\hline & & $\bar{X} g$ & $\bar{X}_{1}$ & $\mathrm{SD}_{1}$ & $\bar{X}_{1}$ & $\mathrm{SD}_{1}$ & \\
\hline 1 & Protect company name and resources from hackers & 4.06 & 4.03 & 0.98 & 4.00 & 0.75 & HR \\
\hline 2 & Segmenting the market according to customers' needs & 4.36 & 4.72 & 0.71 & 4.00 & 0.75 & HR \\
\hline 3 & $\begin{array}{l}\text { Making goods and services available at the right place, } \\
\text { price and with right communication }\end{array}$ & 4.09 & 4.25 & 0.75 & 3.92 & 0.72 & HR \\
\hline 4 & Identify the new trends in marketing environments & 3.94 & 3.91 & 1.06 & 3.96 & 0.71 & HR \\
\hline 5 & Identify the potential partners & 3.62 & 3.71 & 0.84 & 3.53 & 0.72 & HR \\
\hline 6 & $\begin{array}{c}\text { Using social networking and direct marketing to market } \\
\text { business products }\end{array}$ & 4.00 & 4.00 & 0.98 & 4.00 & 0.75 & HR \\
\hline 7 & Forecasting, estimation and marketing and information research & 4.34 & 4.75 & 0.75 & 3.92 & 0.72 & HR \\
\hline 8 & Determine and interpret competitors strength and weaknesses & 4.00 & 4.04 & 1.04 & 3.96 & 0.70 & HR \\
\hline 9 & Knowledge of capturing and retaining customers & 3.79 & 3.98 & 1.02 & 3.60 & 0.96 & HR \\
\hline \multirow[t]{2}{*}{10} & Knowledge of seasonal fluctuations of goods in the market & 3.84 & 389 & 1.15 & 3.79 & 1.04 & HR \\
\hline & Grand mean & 400 & & & & 0.79 & \\
\hline
\end{tabular}

\section{Discussion of the Findings}

The findings revealed that forty (40) entrepreneurial skill needs items for self sustainability by secretarial education graduates were highly required for them to function effectively in the business enterprises in Enugu State. The result of this study agreed with the findings of Meredith, Nelson and Neck [10] and Uko [11] that entrepreneurial skills are required to manipulate input resources effectively within a particular enterprise to achieve the production goal. This implies that skills possessed by an entrepreneur will enable him to undertake an enterprise. This is in conformity with Schumpeter in Etonyeaku [8] that entrepreneurial skills are potentials required by workers through training, which ensures proficiency and competency in the performance of occupational tasks for economic benefits.

The findings in Table 1 revealed that all the managerial skills are highly required to achieve a self-sustainability. Osborne [3] opined that managerial skills are the various steps needed by an entrepreneur to mobilize men, money, machine, material and financial resources in order to produce new products. The findings of the study were in line with the findings of Ezeh and Eze [12] that managerial skills include adopting basic steps in starting a business, delegate authority and monitor performance, determine risks and risk management, among others. 
Table 4. Mean responses of respondents on ICT skill needs required by secretarial education graduates for self-sustainability $\mathrm{N}=238$.

\begin{tabular}{|c|c|c|c|c|c|c|c|}
\hline \multirow[t]{2}{*}{$\mathrm{S} / \mathrm{N}$} & \multirow[t]{2}{*}{ ICT Skill Requirement } & \multirow[b]{2}{*}{$\bar{X} g$} & \multicolumn{2}{|c|}{$\begin{array}{l}\text { Lecturers } \\
\mathrm{n}=54\end{array}$} & \multicolumn{2}{|c|}{$\begin{array}{c}\text { Students } \\
\mathrm{n}=154\end{array}$} & \multirow[t]{2}{*}{ Remark } \\
\hline & & & $\bar{X}_{1}$ & $\mathrm{SD}_{1}$ & $\bar{X}_{1}$ & $\mathrm{SD}_{1}$ & \\
\hline 1 & Operate the computer & 3.94 & 3.96 & 0.94 & 3.91 & 1.02 & HR \\
\hline 2 & Create, format, save and print documents & 4.27 & 4.27 & 0.71 & 4.27 & 0.74 & HR \\
\hline 3 & Create a website & 4.29 & 4.61 & 0.75 & 3.96 & 0.70 & HR \\
\hline 4 & Access the internet through the use of mobile phones/telephone & 3.81 & 3.91 & 1.06 & 3.71 & 1.28 & HR \\
\hline 5 & Use scanning machines to send messages & 3.97 & 3.96 & 0.92 & 3.97 & 1.06 & HR \\
\hline 6 & Produce text documents & 3.37 & 3.43 & 1.61 & 3.31 & 1.05 & HR \\
\hline 7 & Browse and download information from the internet & 4.33 & 4.00 & 0.77 & 4.66 & 0.66 & HR \\
\hline 8 & Conference calls/video conferencing for staff meetings & 3.35 & 3.60 & 1.45 & 3.10 & 1.17 & SR \\
\hline 9 & $\begin{array}{l}\text { Database Microsoft access for storage and administration } \\
\text { of staff data }\end{array}$ & 3.94 & 3.91 & 1.06 & 3.96 & 0.74 & HR \\
\hline \multirow[t]{2}{*}{10} & $\begin{array}{l}\text { Spreadsheets like-Microsoft excel to manage the } \\
\text { company's budget }\end{array}$ & 3.59 & 3.97 & 1.06 & 3.20 & 1.20 & HR \\
\hline & Cluster grand mean & 3.89 & & & & & \\
\hline
\end{tabular}

The result of the hypothesis tested showed that there was no significant difference in the mean rating of the responses of the lecturers and students on managerial skills required for self sustainability by secretariat education graduates.

The findings of the study in Table 2 revealed that all the ten technical skills were highly required by secretarial education graduates for self sustainability. This is in line with Odu (2009) that technical skills are needed for successful enterprise because these skills are necessary for securing and holding employment in a recognized occupations. Also technical skills are required to enable the graduates to perform effectively in their enterprise. The result also support Whetten and Cameron [13] that technical skills are mainly on work settings because the major goal of any skill is to help prepare the worker to improve on his competency in managerial role. The result of the null hypothesis showed that there was no significant difference between the opinion of lecturers and students as regards the technical skills required for self sustainability.

Data presented in Table 3 revealed that marketing skills are highly required for any effective enterprise. The finding revealed that marketing skills are required to identify new trends in the environment, knowledge of seasonal fluctuations and segmenting marketing according to customers' needs. This is in line with Kotler and Keller [14] that marketing is meeting consumers' needs profitably and satisfying them by communicating marketing ideas to the consumers. It was found that overall marketing skills were highly required for with Okafor, Okeme and Oketobo [15] that entrepreneurial skills are required by women retirees for marketing fruit juice as a sustainable business in all the 10 marketing skills identified were above the cut off mean, indicating the that all the rated skills were required by the graduates in marketing their products.

The findings on ICT skills in Table 4 revealed that the ten skills are required by secretarial education graduates to achieve success in business enterprise. These findings are corroborated by the findings in the work Ojukwu and Ojukwu [16] that ICT skills should include; word processing skills such as formatting editing keyboarding, ability to use scanning machines, to select reproduction activities. According to Osuala [17] business operators use word processing for memos, reports, correspondence, among others. ICT skills are necessary tools for business operators because many people who do not own personal computers, go to business centres to type their documents.

\section{Conclusion}

Based on the findings of this study, it could be concluded that entrepreneurial skills are required for effective business operation. Lack or absence of these skills affects graduates in embarking on any business venture. The entrepreneurial skills would enable the graduates to handle all types of documents for their customers and thereby meet their customers' satisfaction successfully. The skills could serve both as operational guidelines for those in the business as well as training package for new entrants. The study has provided information on entre- 
preneurship skills that are required for sustainable business operation. Therefore, the secretarial education graduates need to combine all the skills identified or listed therein for effective business management.

\section{Recommendations}

Based on the findings, the following recommendations were made:

1) Secretarial education graduates should endeavour to acquire themselves with all the relevant skills necessary for them to create, and maintain their customers’ needs;

2) The findings of this study should also be made available to skills acquisition centres as a training manual;

3) It is recommended that all those who are not ICT compliant should acquire the skills to be relevant in the society.

\section{References}

[1] Federal Republic of Nigeria (2004) National Policy on Education. Nigerian Educational Research and Development Council. (NERDC) Press, Lagos.

[2] Okorie, J.U. (2000) Developing Nigeria’s Workforce. Menty Envious Publishers, Calabar.

[3] Osbourne, S.O. (2000) Entrepreneurship Studies in Practice. Integrated Journal of Labour and Organization Psychology, 2, 90-96.

[4] Jain, G.R. (2013) Capacity Building of TVET in Entrepreneurship. Union International UK and African Development Bank. An Unpublished Workshop Memograph, Calabar.

[5] Arogundade, B.B. (2011) Entrepreneurship Education: An Imperative for Sustainable Development in Nigeria. Journal of Emerging Trends in Educational Research and Policy Studies (JETERAPS), 2, 26-27.

[6] UNESCO (2006) Start My Own Small Business. A Training Module on Entrepreneurship for Students of Technical and Vocational Education and Training (TVET) at Secondary School Level Pairs, UNESCO Section for Technical and Vocational Education.

[7] Anyakoha, E.U. (2009) New Entrepreneurship Education and Wealth Creation Strategies: Practical Tips for Economic Empowerment and Survival. Great AP Express Publishers Limited, Nsukka.

[8] Etonyeaku, E.A.C. (2011) Entrepreneurial Skills Required by Youths for Effective Marketing of Agricultural Products in Nsukka Agricultural Zone of Enugu State, Nigeria. Nigerian Vocational Association Journal, 16, 38-43.

[9] Ezeji, S.C.O.A. (2004) Basic Principles of Research in Education. Cheston Agency Ltd., Enugu.

[10] Meredit, G.G., Nelson, R.E. and Neck, P.A. (1996) The Practice of Entrepreneurship. Nigeria University of Lagos Press, Lagos

[11] Uko, E.O. (2009) Resource Management Education Needs of See School Graduates for Their Economic Success in Oil Palm Production Enterprise in Akwa Ibom State. Unpublished Ph.D. Thesis, University of Nigeria, Nsukka.

[12] Ezeh, P.C. and Eze, M.E. (2011) Determination of Skills Required by Business Centre Operators for Success in Business Centre Management in Ida LGA of Kogi State. Nigerian Vocational Association Journal (NVA), 16, 125-133.

[13] Whetten, D.A. and Cameron, K.S. (2005) Developing Management Skills. 6th Edition, Pearson Education Inc., Upper Saddle River.

[14] Kotler, P. and Keller, K.C. (2010) Marketing Management. PHI Learning, Private Limited, Connaught Circus, New Delhi

[15] Okafor, M.B., Okeme, I. and Oketobo, E.A. (2010) Entrepreneurial Skills Required by Secondary School Graduates in Palm Oil Processing in Anambra State. Nigeria Vocational Association Journal, 15, 282-289.

[16] Ojukwu, K. and Ojukwu, F.K. (2002) Competencies Related to Information and Communication Technologies. Business Education Journal, 3, 137-146.

[17] Osuala, E.C. (2004) Principles and Methods of Business and Computer Education. Cheston Agency Limited, Enugu. 
Scientific Research Publishing (SCIRP) is one of the largest Open Access journal publishers. It is currently publishing more than 200 open access, online, peer-reviewed journals covering a wide range of academic disciplines. SCIRP serves the worldwide academic communities and contributes to the progress and application of science with its publication.

Other selected journals from SCIRP are listed as below. Submit your manuscript to us via either submit@scirp.org or Online Submission Portal.
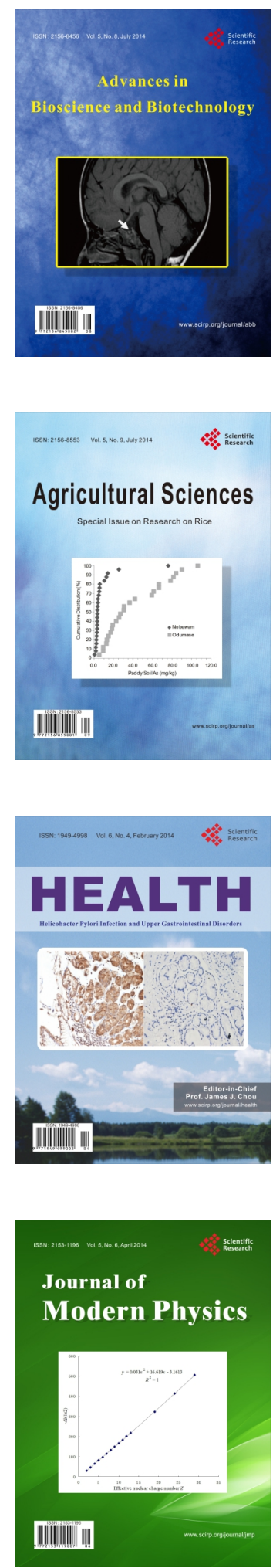
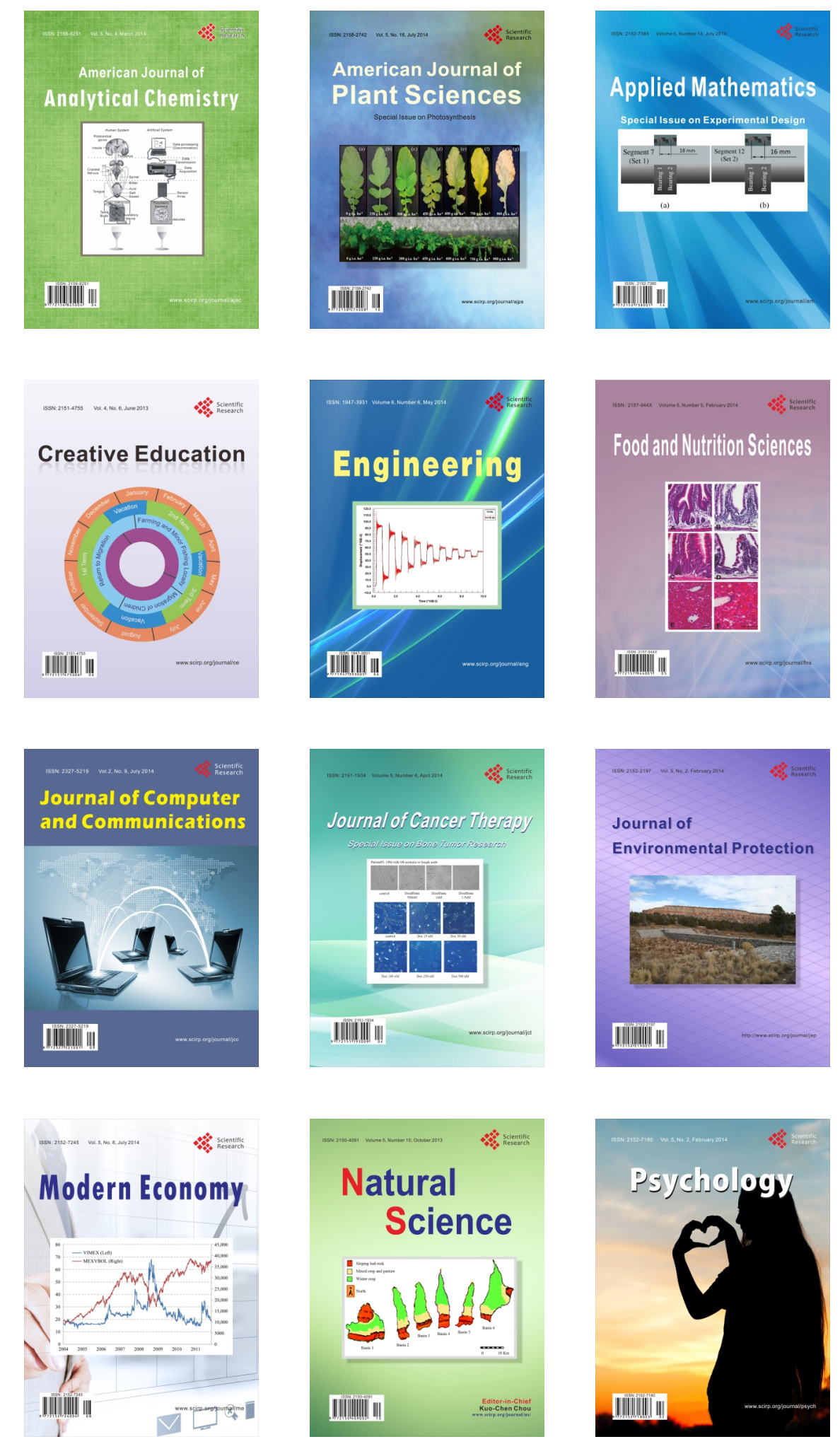